\title{
Swimming into Science: Sharks and Minnows Summer Camp
}
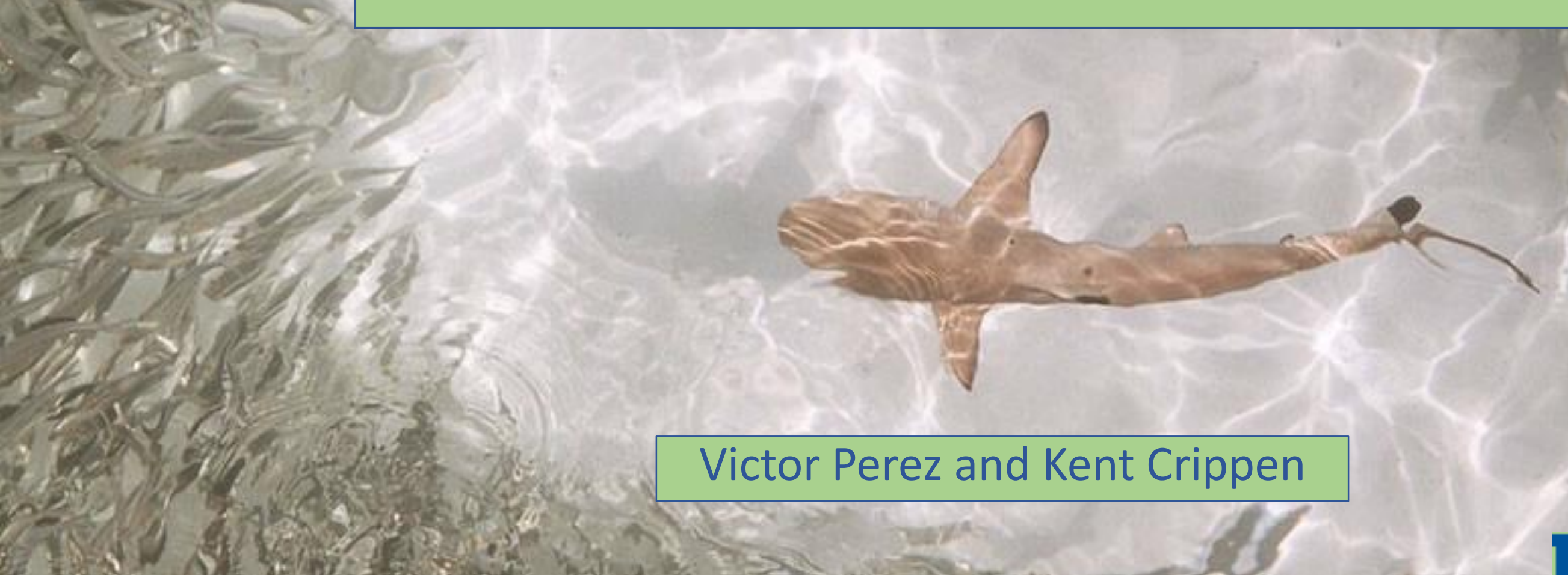

Victor Perez and Kent Crippen

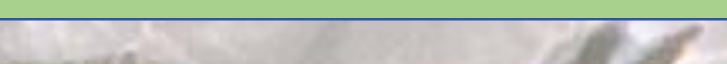

UF INLERRIIDA 


\section{Summer Camp Overview}

- Who?

Elementary-aged students

(Grades 3-4)

- Where?

Florida Museum of Natural History

- How long?

Five half days (June 2018)

- Theme?

STEM careers and Fish

\section{Sharks and Minnows}

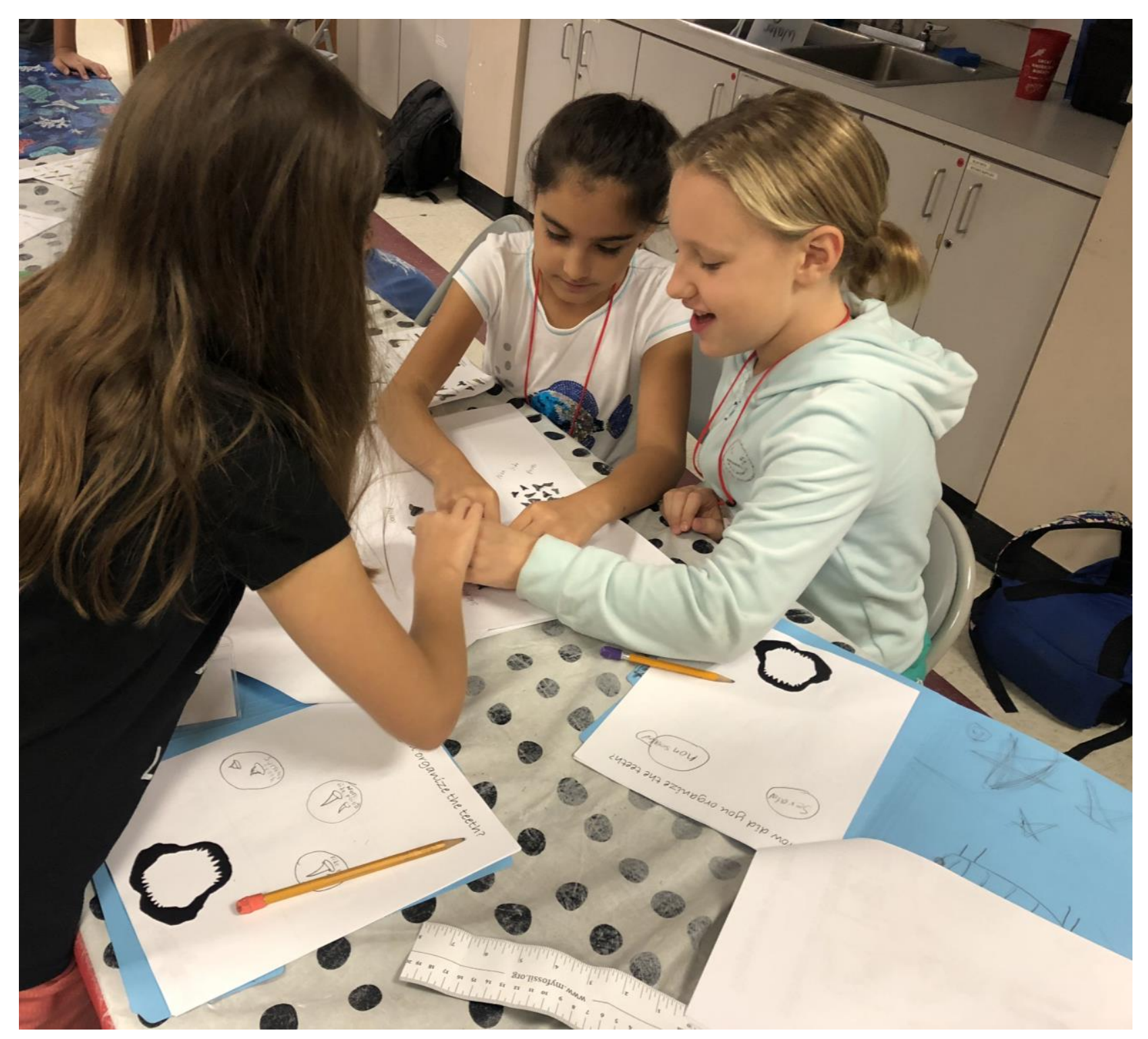




\section{Primary Goals}

1. Increase interest and awareness of STEM careers

2. Identify and address misconceptions about STEM careers

3. Identify and address misconceptions about fish

$$
\text { REPORT TO THE PRESIDENT }
$$

ENGAGE TO EXCEL: PRODUCING ONE MILLION ADDITIONAL COLLEGE GRADUATES WITH

DEGREES IN SCIENCE, TECHNOLOGY, ENGINEERING, AND MATHEMATICS 


\section{Theoretical Framework}

Dorsen's Factors

Career Awareness and

Decision to pursue a STEM career
Brief Description

STEM careers cannot be pursued if students are not aware of them and how they are introduced to those careers will influence their decision to pursue those careers.

\section{Intervention Actions}

Participants were introduced to five STEM careers.

\begin{tabular}{cll}
\hline $\begin{array}{c}\text { Academic Preparation } \\
\text { and Achievement }\end{array}$ & $\begin{array}{l}\text { Academic preparation should be augmented with } \\
\text { informal extracurricular STEM experiences, } \\
\text { which will in turn enhance interest and } \\
\text { performance in formal classrooms. }\end{array}$ & $\begin{array}{l}\text { Camp activities were aligned to Florida's K-12 } \\
\text { teaching standards (NGSSS) to augment formal } \\
\text { education. }\end{array}$ \\
\hline $\begin{array}{c}\text { Identification with } \\
\text { STEM Careers }\end{array}$ & $\begin{array}{l}\text { Students must envision themselves in STEM } \\
\text { careers, which can be facilitated by role models } \\
\text { and/or real-world experiences. }\end{array}$ & $\begin{array}{l}\text { Participants experienced authentic STEM practice } \\
\text { and met early career professionals (role models). }\end{array}$ \\
\hline $\begin{array}{c}\text { Self-efficacy } \\
\text { External Environmental } \\
\text { Factors }\end{array}$ & $\begin{array}{l}\text { Students must feel confident in their ability to } \\
\text { succeed in STEM careers. }\end{array}$ & $\begin{array}{l}\text { Implemented a validated survey to measure } \\
\text { attitudes towards STEM careers. }\end{array}$ \\
$\begin{array}{cll}\text { (Barriers and Supports) } \\
\text { Interest, Enjoyment, and student's perception of STEM. } \\
\text { Motivation }\end{array}$ & $\begin{array}{l}\text { Positive childhood experiences have a strong } \\
\text { impact on STEM career pathways. }\end{array}$ & $\begin{array}{l}\text { The summer camp is a STEM-related life } \\
\text { experience. }\end{array}$ \\
\hline
\end{tabular}

Academic Preparation

Academic preparation should be augmented with

Camp activities were aligned to Florida's K-12 teaching standards (NGSSS) to augment formal which will in turn enhance interest and Participants experienced authentic STEM practice STEM Careers careers, which can be facilitated by role models and/or real-world experiences. succeed in STEM careers. Implemented a validated survey to measure careers.

\section{External Environmental} itive and negative, experience. 


\section{Evaluation Plan}

\section{Front-end \\ (Needs Assessment)}

$>$ Prior to implementation

Compromise between my interests and the museum's needs

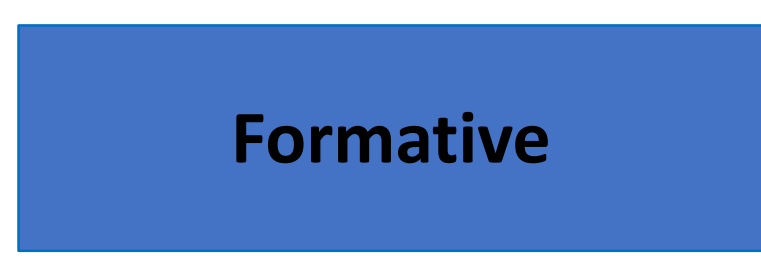

$>$ During implementation

$>$ Students filled out scientific notebooks throughout the week (formative assessment tasks)

\section{Summative}

$>$ After implementation

$>$ Pre/Post validated survey on attitudes towards STEM careers 


\section{A Day in the Life of a Camper...}

1. Introduce topic

2. Draw a Scientist Activity

3. Role Model Visit

4. Inquiry Activity 1

5. Museum excursion

6. Snack Break

7. Inquiry Activity 2

8. Inquiry Activity 3

9. Reflection

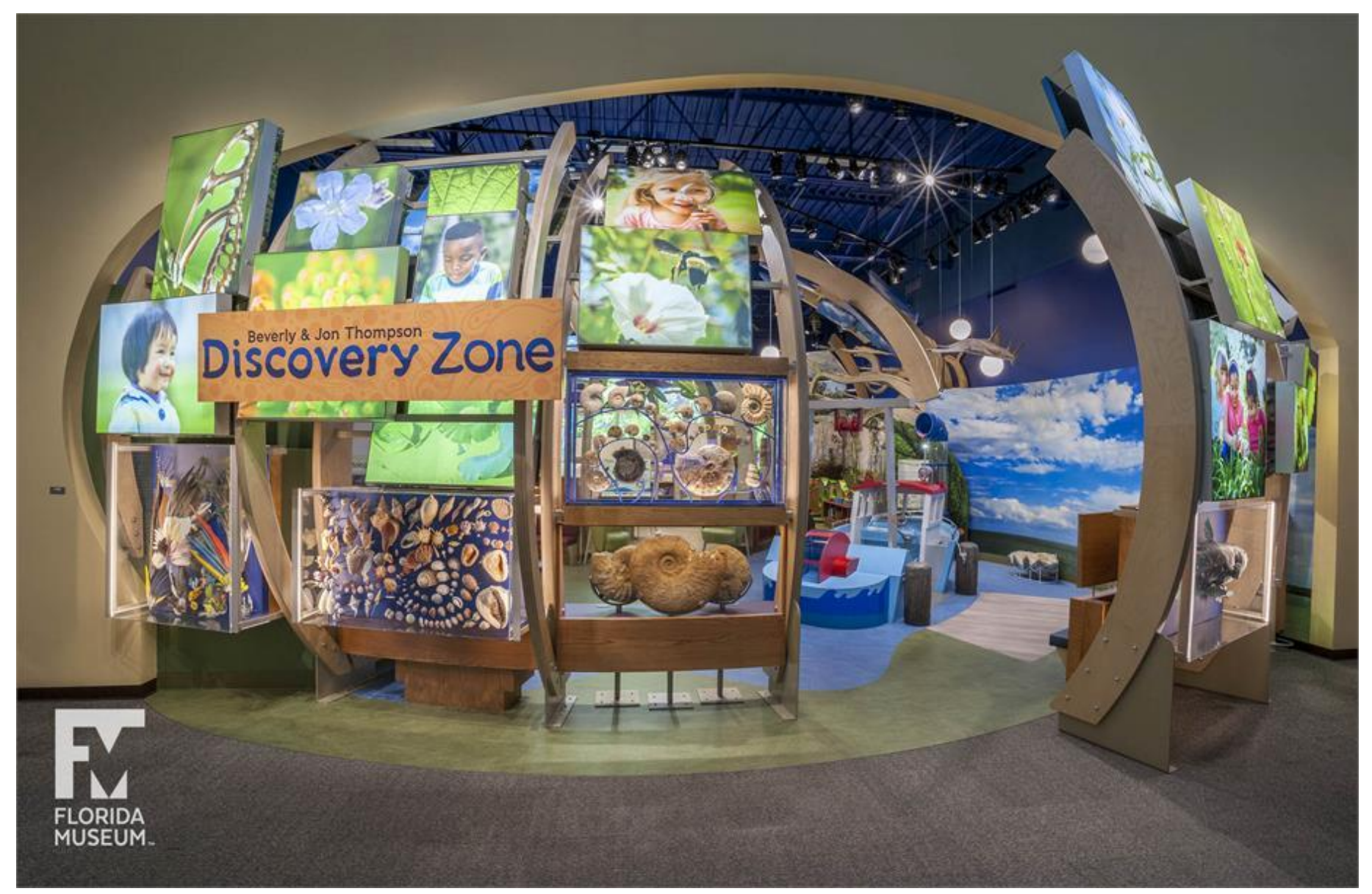




\section{Day 1: Fish Anatomy and Classification}

- Driving Question: What are fish skeletons made of?

- Learning Objectives: After day one, campers will be able to:

- explain how living bony fish, sharks, and rays are classified.

- relate body shape to locomotion.

- understand the compositional differences between bone, cartilage, and teeth.

-Words to Know: Vertebrate, Chondrichthyes, Osteichthyes, Cartilage, Phosphate, Enamel, Dentine, Crown, Root

- Career Highlight: Biologist - someone that studies living organisms 


\section{Day 1: Fish Anatomy \& Classification}

Today we will:

- explain how living bony fish, sharks, and rays are classified.

- relate body shape to locomotion.

- understand the differences between bone, cartilage, and teeth.

What are fish skeletons made of? 


\section{Formative Assessment Task:}

1. Lab Coat

2. Eyeglasses

3. Facial Hair

4. Symbols of Research

5. Symbols of Knowledge

6. Technology

7. Relevant Captions

1. Male Gender

2. Caucasian

3. Indications of Danger

4. Presence of Light Bulbs

5. Mythic Stereotypes

6. Indications of Secrecy

7. Working Indoors

8. Middle Age or Elderly

9. Open Comments

\section{Draw-a-Scientist Test Checklist (DAST-C)}

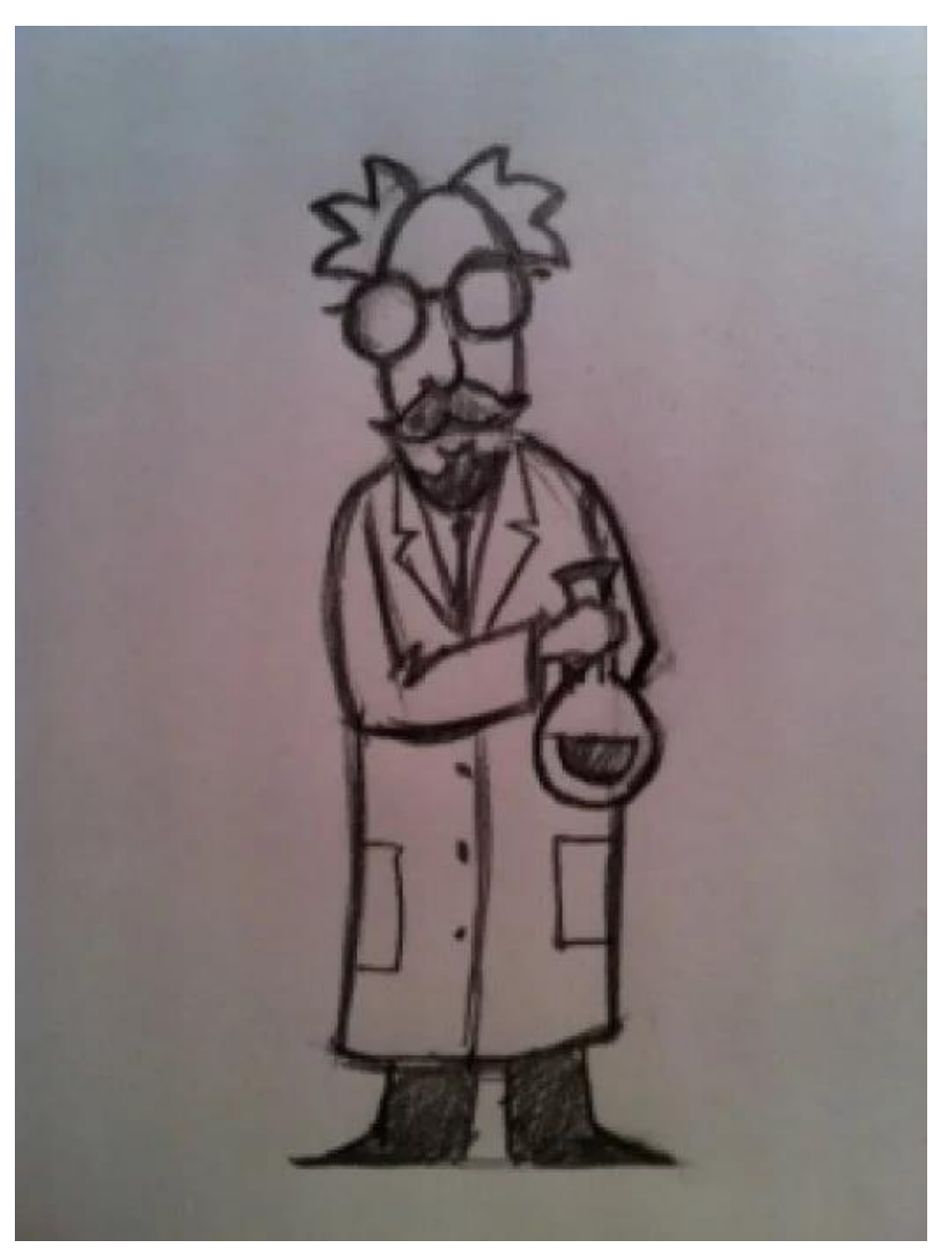

Chambers (1983) \& Finson et al. (1995) 


\section{Preliminary Results}

- Participants: $\mathrm{N}=18$

- 9 Male, 9 Female

- \# of Drawings: $\mathrm{N}=80$

- Biologist: $n=15$

- Paleontologist: $n=18$

- Geologist: $n=15$

- Ecologist: $n=16$

- Engineer: $n=16$

\begin{tabular}{|l|l|l|}
\hline Stereotype & Frequency & Uncertain \\
\hline Lab Coat & $15 \%$ & $5 \%$ \\
\hline Eyeglasses & $2.5 \%$ & $0 \%$ \\
\hline Facial Hair & $3.75 \%$ & $0 \%$ \\
\hline Symbol of Research & $63.75 \%$ & $0 \%$ \\
\hline Symbol of Knowledge & $11.25 \%$ & $0 \%$ \\
\hline Technology & $83.75 \%$ & $0 \%$ \\
\hline Relevant Caption (ex. "Eureka!") & $16.25 \%$ & $0 \%$ \\
\hline Male Gender & $48.75 \%$ & $13.75 \%$ \\
\hline Caucasian & $87.5 \%$ & $10 \%$ \\
\hline Indications of Danger & $6.25 \%$ & $0 \%$ \\
\hline Presence of Light Bulbs & $2.5 \%$ & $0 \%$ \\
\hline Mythic Stereotypes (ex. Mad & $22.5 \%$ & $0 \%$ \\
\hline Scientist) & & \\
\hline Indications of Secrecy & $0 \%$ & $0 \%$ \\
\hline Working Indoors & $27.5 \%$ & $3.75 \%$ \\
\hline Middle aged or Elderly & $2.5 \%$ & $1.25 \%$ \\
\hline
\end{tabular}




\section{Biologist}

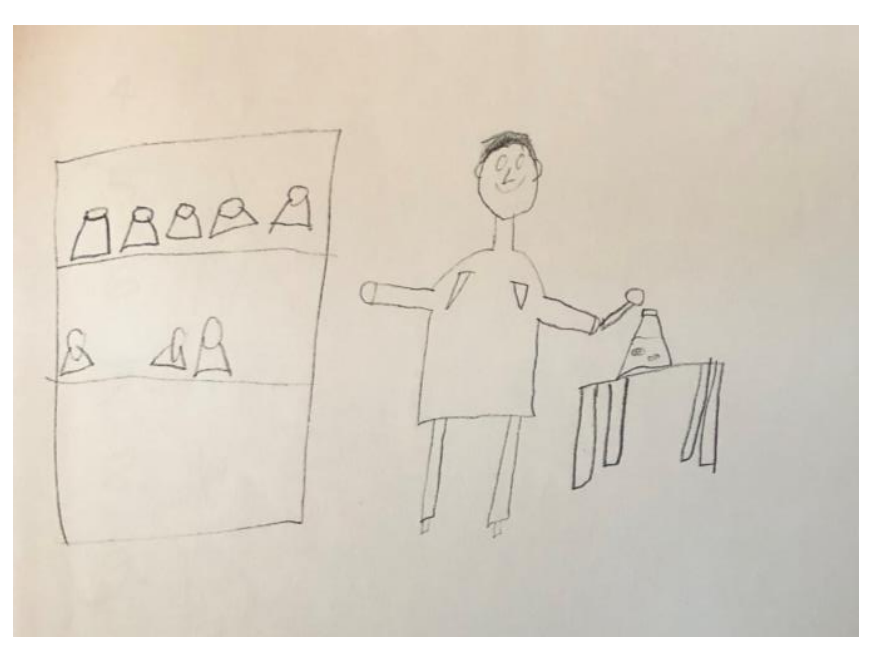

Ecologist

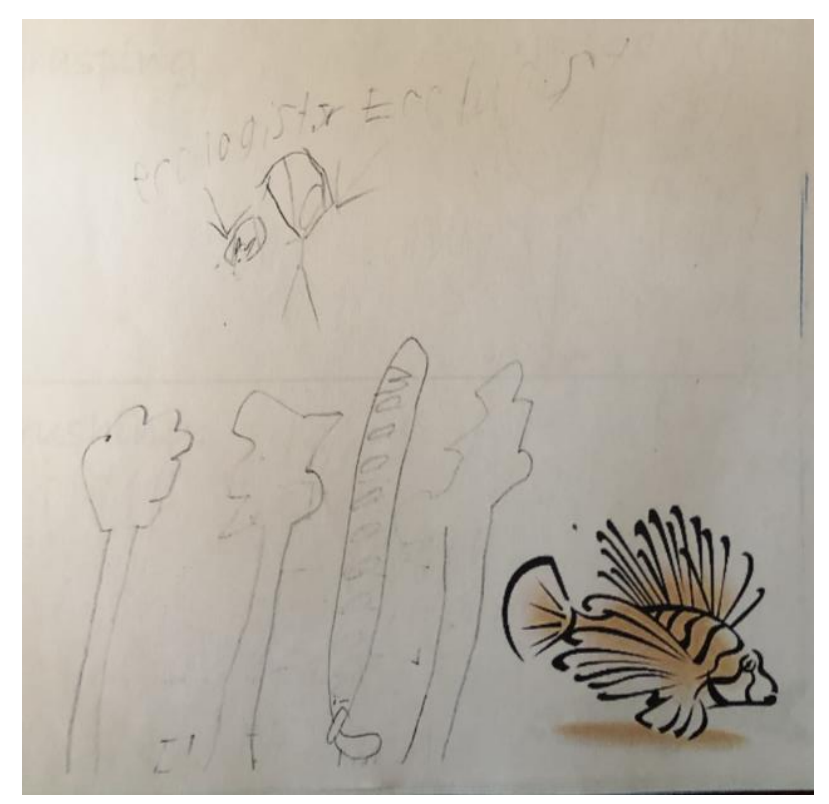

Paleontologist

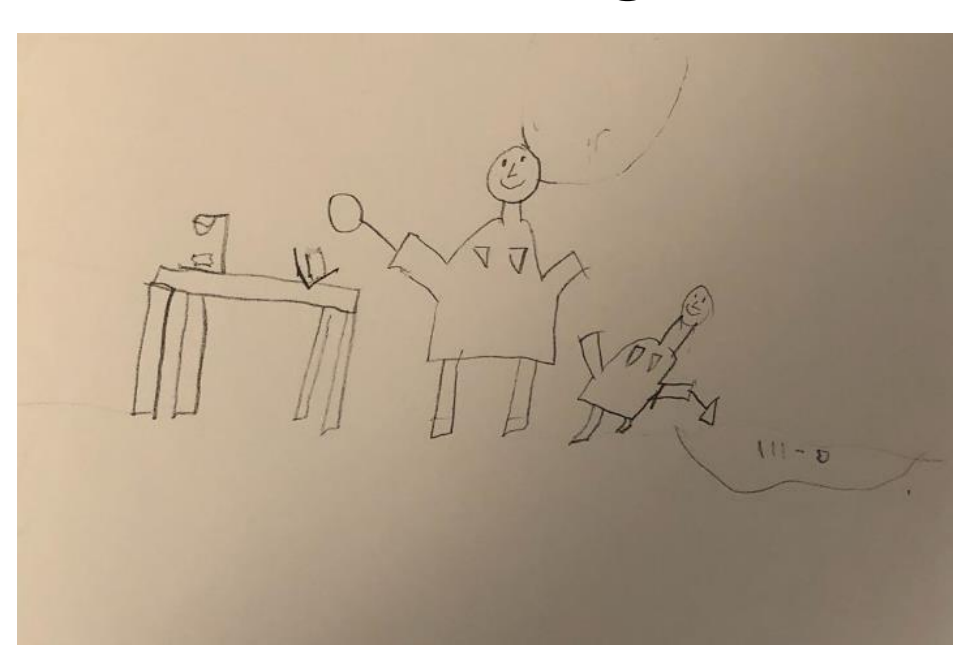

Geologist

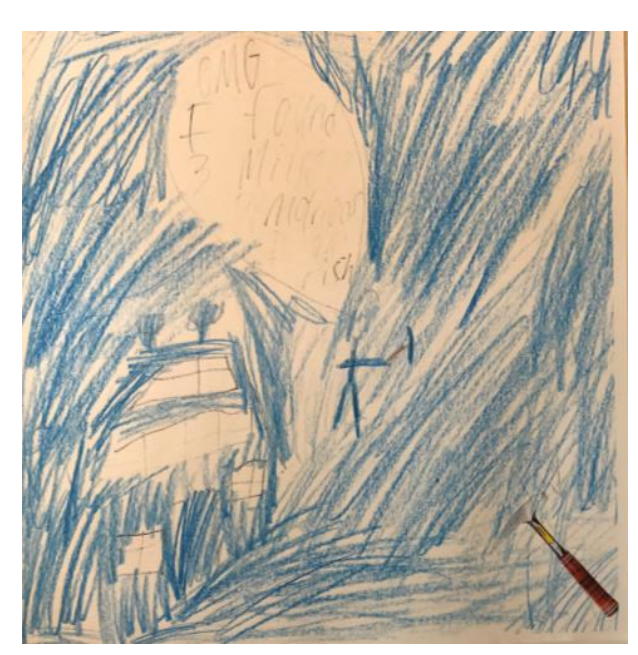

\section{Engineer}

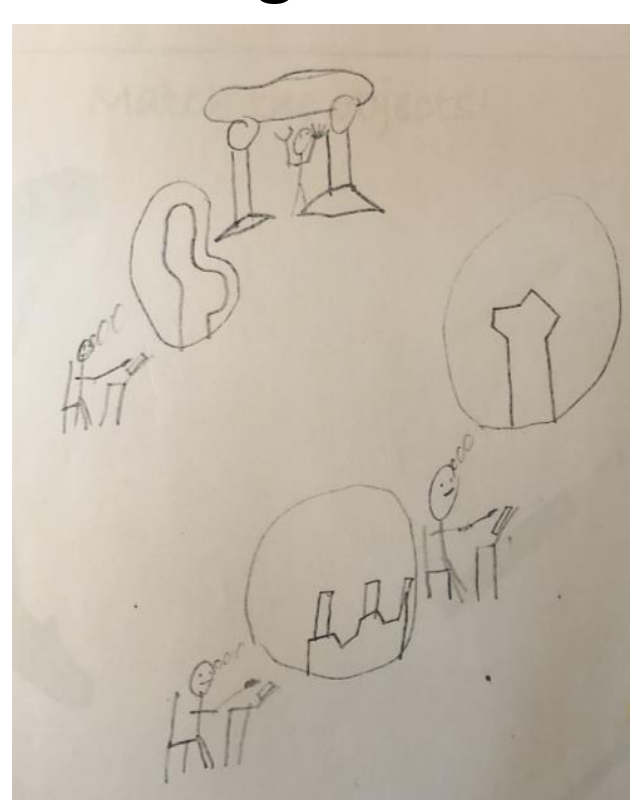

\section{Observations}

- Does not self-identify

- Non-descript appearance

- Loss of lab coat

- Location varies with profession

- Biologist = Chemist

- Geologist is sensationalized 
Biologist

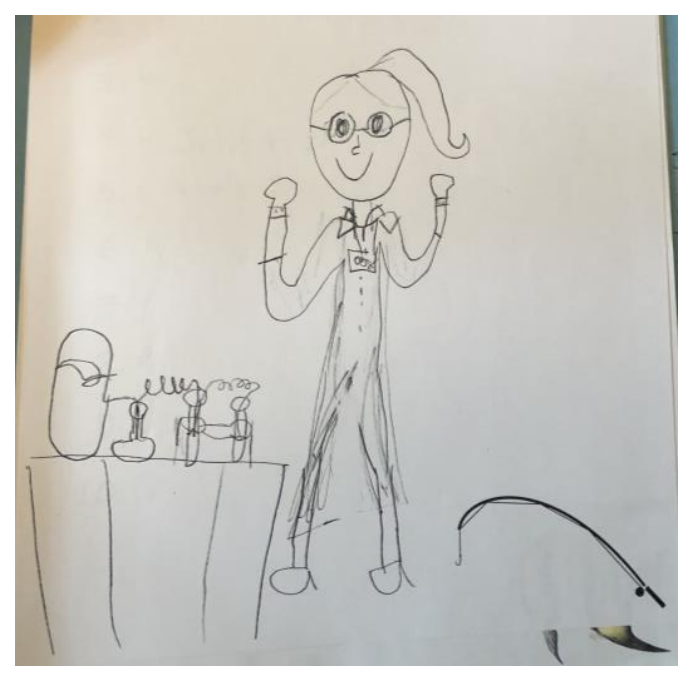

Ecologist

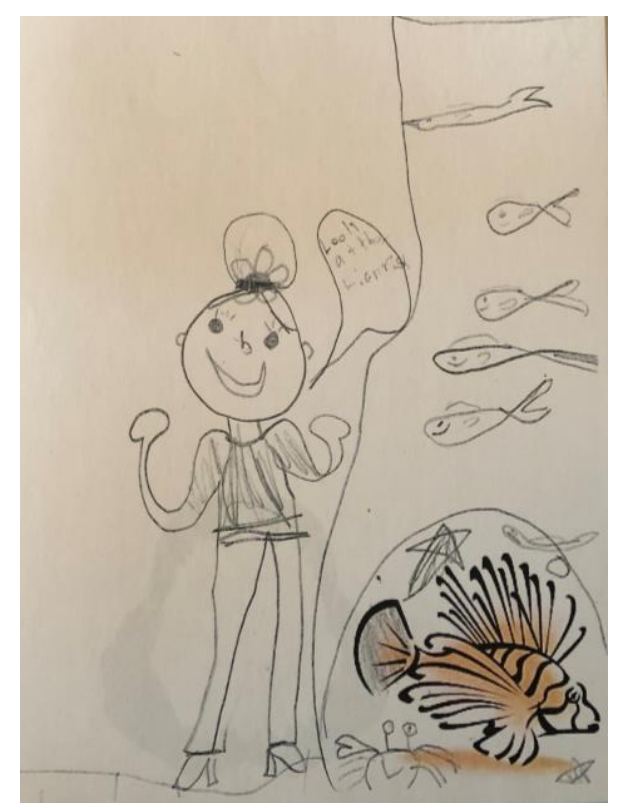

Paleontologist

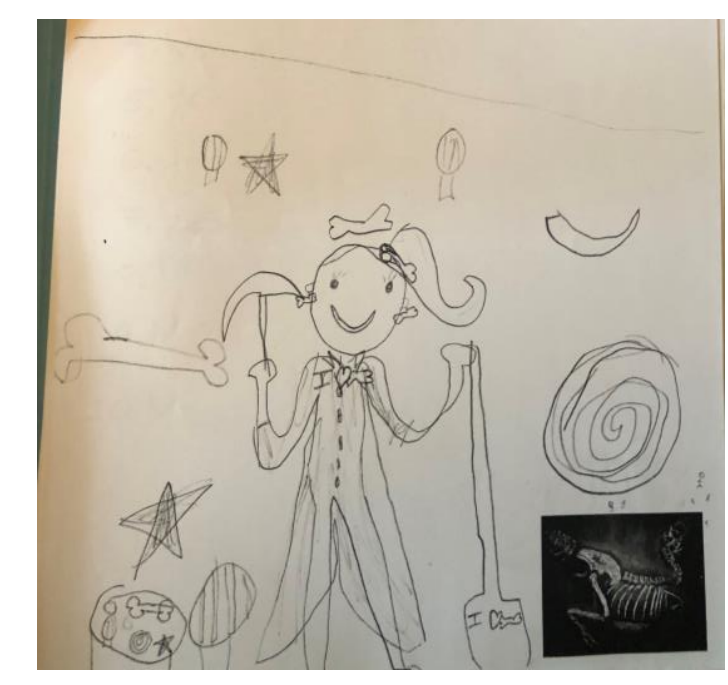

Engineer

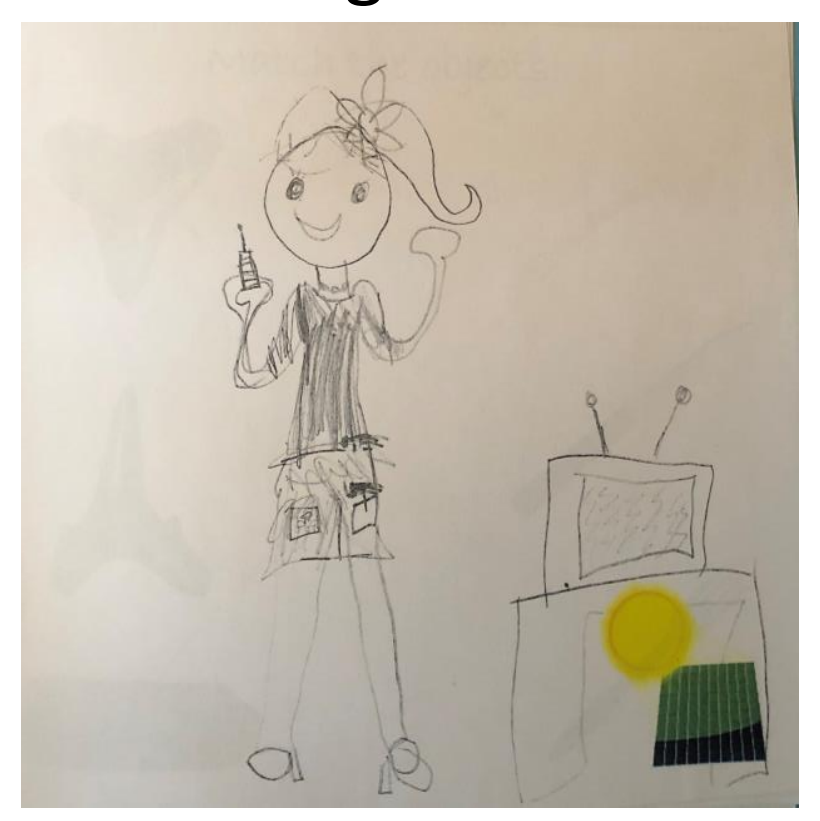

Geologist

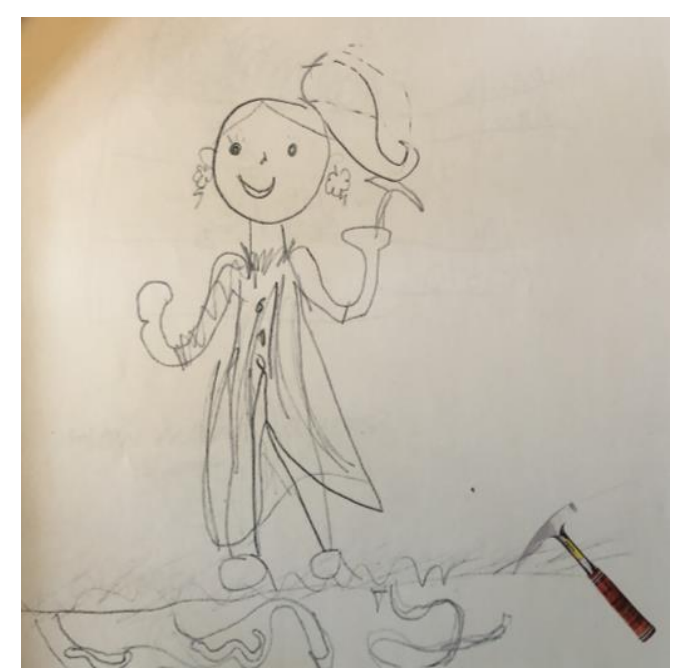

\section{Observations}

- Self-identifies with professions

- Depicts practice

- Change in appearance

- Location varies with profession

- Strong overlap between paleontologist and geologist 


\section{Biologist}
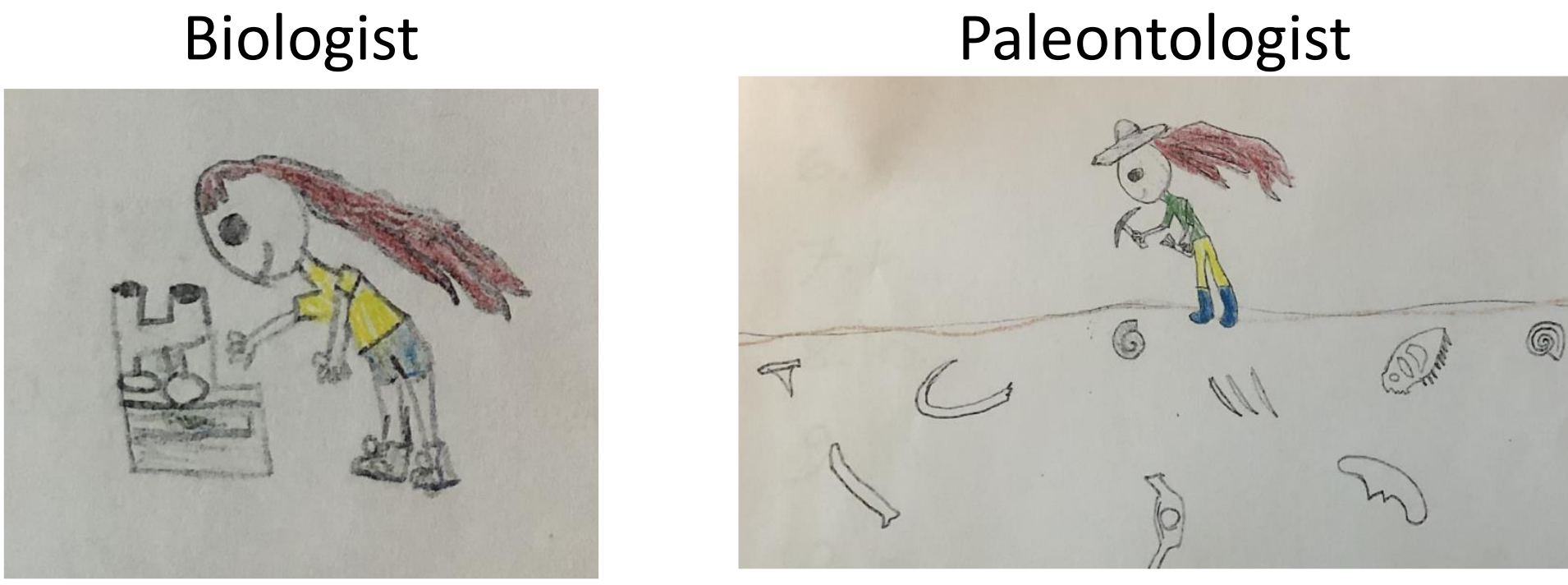

\section{Ecologist}

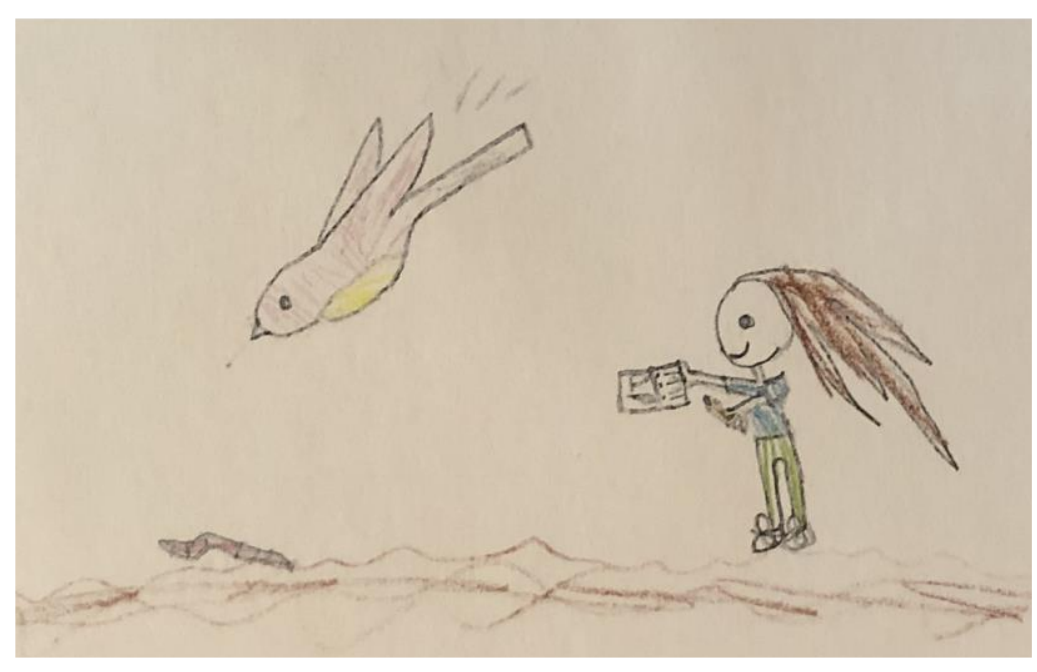

Engineer

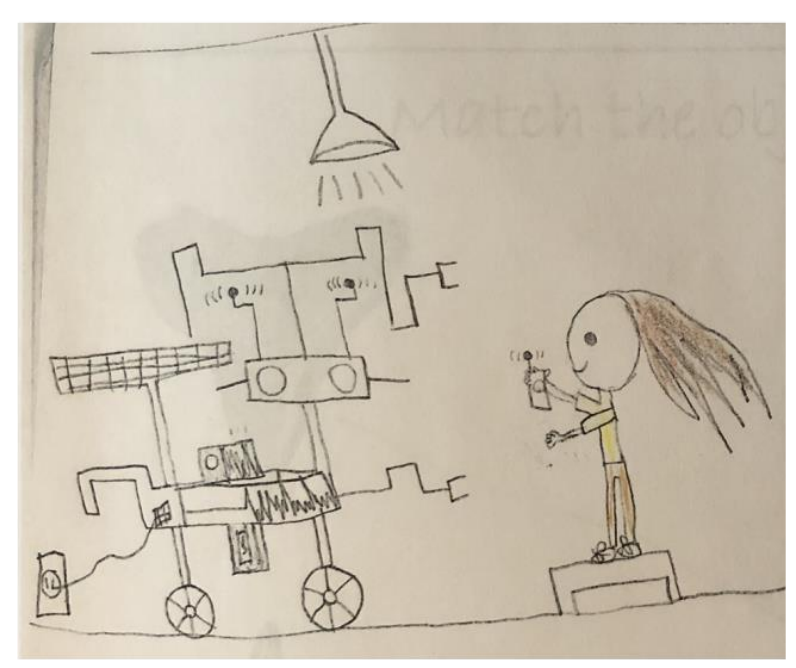

Geologist

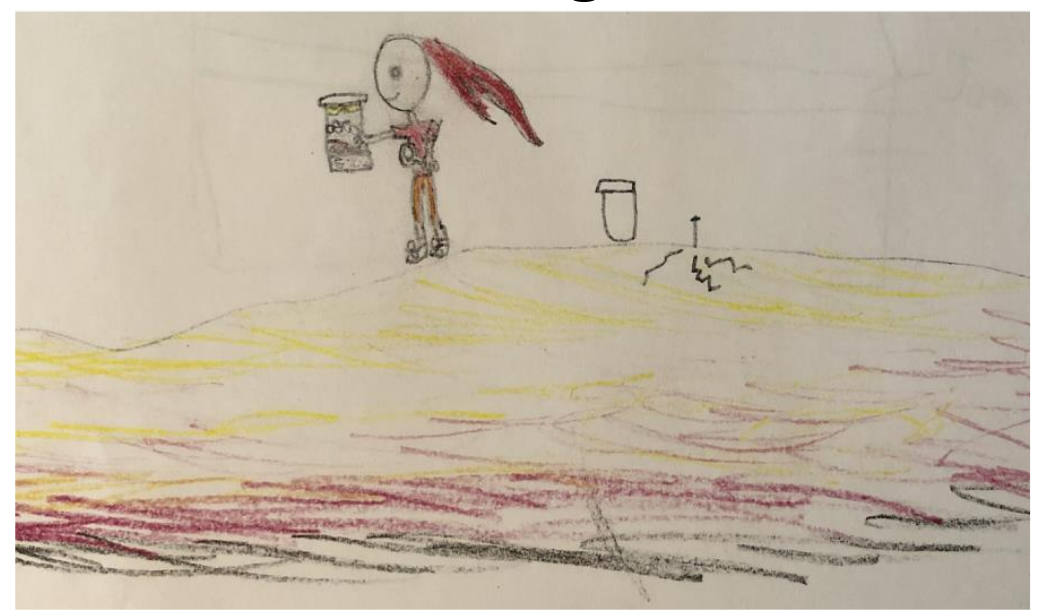

\section{Observations}

- Self-identifies with professions

- Depicts practice at high level

- Location varies with profession

- Strong differentiation between professions 


\section{Summary}

DAST-C Results:

- Very few stereotypes about appearance, with the exception of ethnicity

○ Lab coat (15\%), Eyeglasses (2.5\%), Facial Hair (4\%), Elderly (2.5\%), Caucasian (87.5\%)

- Many depictions of research and technology

- Gender largely reflected participant demographic

o $49 \%$ male $(n=39), 40 \%$ female $(n=32)$

Awareness of STEM careers:

- Biologist were often associated with chemistry and working indoors

- Ecology was often associated with animals and working outdoors

- Geology often sensationalized as rich, gem and mineral hunters

- Geology and paleontology were very similar and always depicted outdoors

- Engineers were typically associated with fixing/building 


\section{$\underline{\text { Next Steps }}$}

1. Validate DAST-C results with additional coders

2. Apply the Draw-an-Engineer Test (DAET)

3. Align observed trends in drawings to written responses in journals and results of validated survey

4. Analyze drawings of fish and written responses to identify misconceptions 
Acknowledgements

Bruce MacFadden

Kent Crippen

FLMNH Education Staff

Junior Volunteers
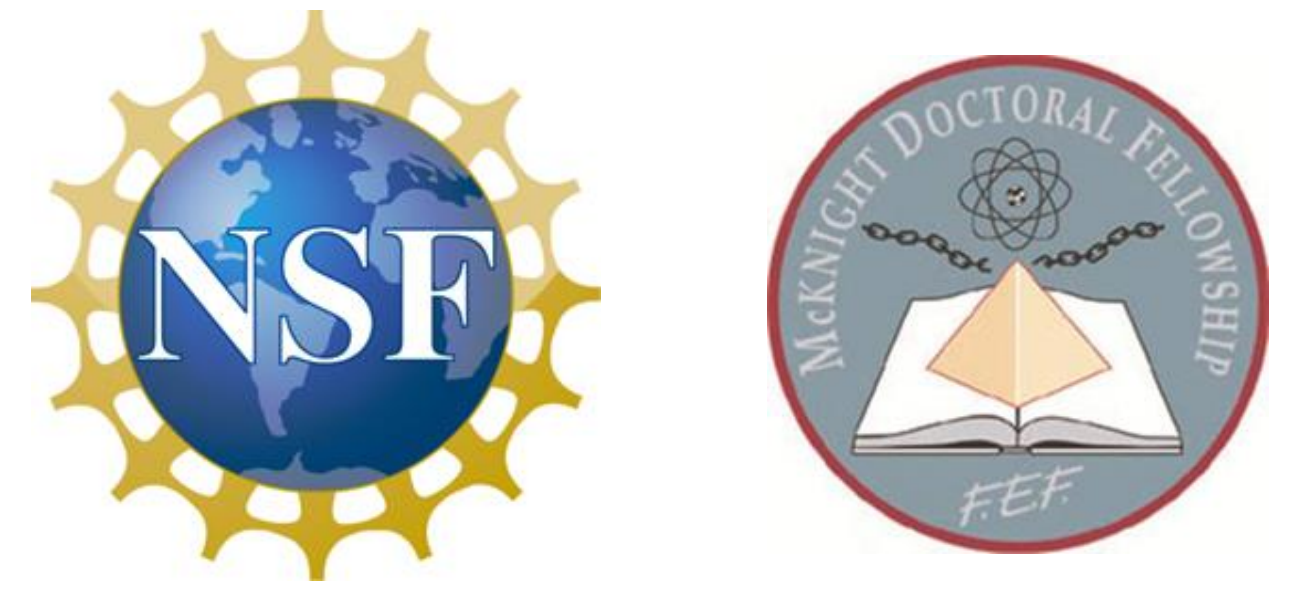
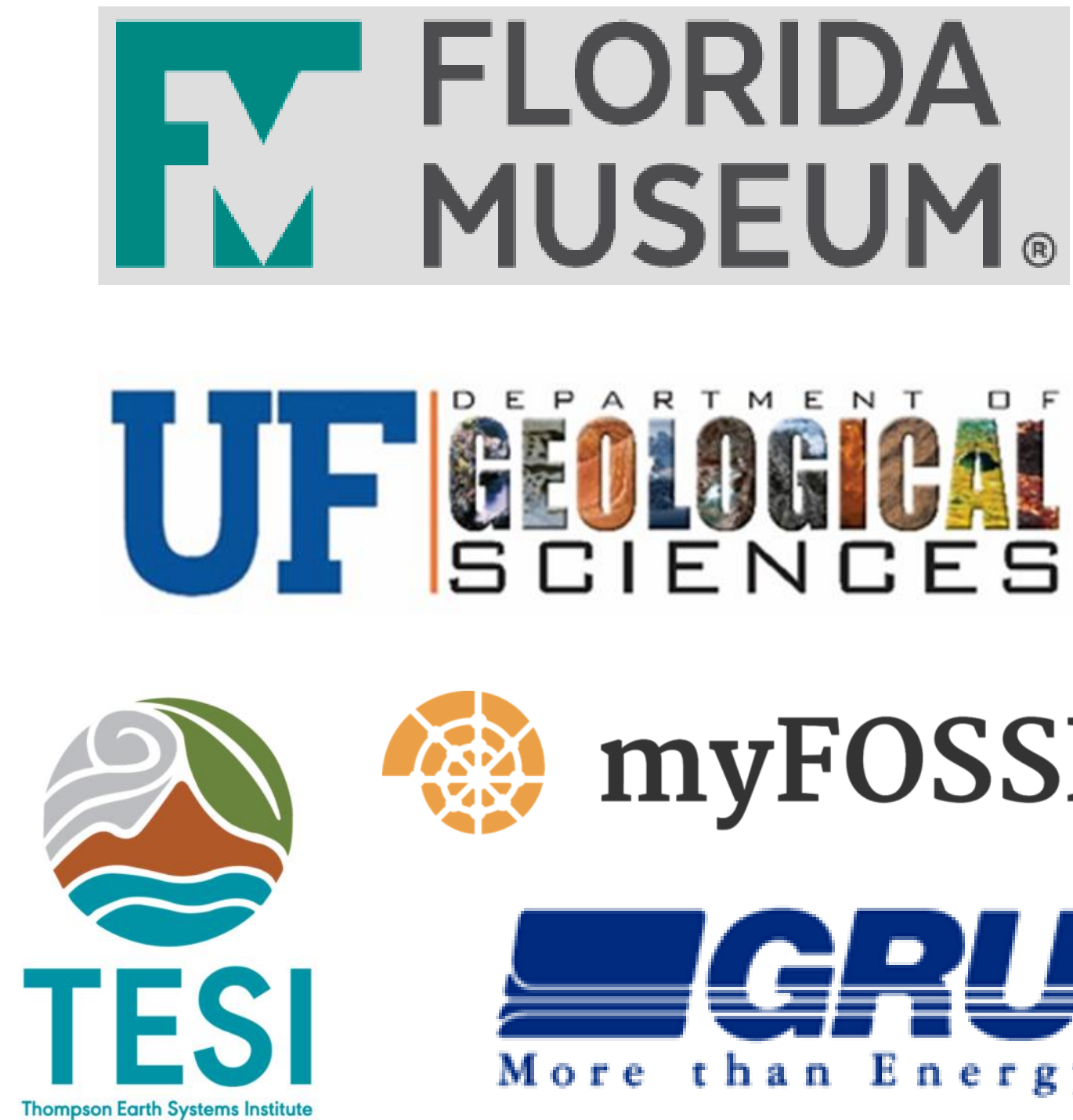

MyFOSSIL

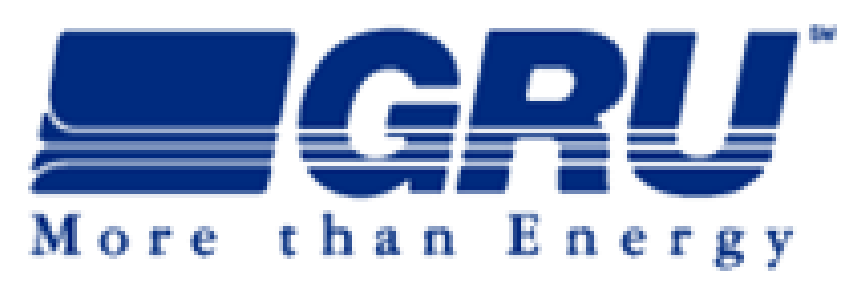

NSF Grant No. DGE-1315138; DGE-1842473; DRL-1322725 